\title{
A Literature Review on Financing Constraints
}

\author{
MA Juntao ${ }^{1, a}$, WANG Shixuan ${ }^{2, b,}$, , GAO Jie ${ }^{3, c}$ and SUN Wei ${ }^{4, d}$ \\ ${ }^{1}$ Harbin Institute of Technology (Shenzhen), China \\ ${ }^{2}$ Harbin Institute of Technology (Shenzhen), China \\ ${ }^{3}$ Harbin Institute of Technology (Shenzhen), China \\ ${ }^{4}$ University of International Business and Economics, China \\ a1027938802@qq.com, bwangshixuan@hit.edu.cn, jennifergao@hit.edu.cn, \\ dsunwei@uibe.edu.cn
}

Keywords: Financing Constraints, Information Asymmetry, Agency Problems, Transaction Costs

\begin{abstract}
Financing constraints reduce the investment opportunities of enterprises and limit the development of enterprises. Based on the existing literature, this review summarizes the relevant research on financing constraints in recent years, and focuses on the causes of financing constraints and the influences of financing constraints. At the end of this review, several feasible suggestions are put forward to relieve financing constraints.
\end{abstract}

\section{Introduction}

Financing constraints have attracted attentions in the company research. According to previous research, financing constraints refer to the fact that in the case of imperfect capital market, the external financing cost of the enterprise is higher than the internal financing cost. These cost differentials lead to the enterprise investment being too dependent on internal funds so that the investment level is lower than the optimal (Fazzari, Hubbard and Petersen, 1988). They point out that the dependence of corporate investment expenditure on internal cash flow reflects the degree of external financing constraints of enterprises. Mcnichols and Stubben (2008) verify the existence of financing constraints through empirical analysis of the sensitivity of enterprise investment and cash flow.

\subsection{Causes of financing constraints}

Financing constraints restrict the development of companies to a certain extent, and it has many causes.

Traditional financing constraints theory holds that information asymmetry, agency problems and transaction costs are the main causes for financing constraints (Myers and Majluf, 1984; Bernanke and Gertler, 1989; Gertler, 1992). In the point of traditional theory, all enterprises face different levels of financing constraints.

Nowadays, the researches related to the causes of financing constraints are more specific, such as government quality, financial transparency, financial reporting quality, and the financial experience of the information publisher and so on (Biddle and Hilary, 2006; Jiang, Shi and Ma, 2016; Li, 2018). The research of Foley-Fisher, Ramcharan and Yu (2016) suggests that unconventional monetary policy might have relieved financial constraints for some firms by inducing gap-filling behavior and affecting bond market risk premia. By studying the relation between financial crisis and financial constraints, Campello, Graham and Harvey (2010) find that many companies are more difficult to obtain external borrowings due to the financial crisis, thus missing many investment opportunities. Chen et al. (2018) prove that in the period of monetary policy tightening, the restraining effect of financing constraints on enterprises' foreign direct investment is more obvious.

\subsection{Influence of financing constraints}

Financing constraints affect the development of enterprises in many different aspects, such as capital structure, company behavior, company performance and so on. 
For capital structure, financing constraints have an impact on leverage ratio, cash flow sensitivity, and leasing. $\mathrm{Ma}$ and $\mathrm{Hu}$ (2012) note that when monetary policy changes affect credit supply, the capital structure of unconstrained firms is less affected by policy tightening, while the leverage ratio of constrained firms decreases (increases) with policy tightening (relaxation). The impact of financial constraints can be reflected by the company's tendency to save cash from cash flow. More specifically, constrained company has positive cash flow sensitivity, while the unconstrained company's cash savings are not related to cash flow (Almeida, Campello and Weisbach, 2004). Rampini and Viswanathan (2013) demonstrate that leasing is a powerful and high-cost financing, allowing greater leverage. The higher the degree of financial constraints is, the more companies lease.

For company behavior, financing constraints have a significant impact on cash dividend payment and cash dividend policy. Quan, Liang and $\mathrm{Fu}(2016)$ test the impact of monetary policy and financing constraints on cash dividend payment. They find corporate financing constraints will further strengthen the restraint of tight monetary policy on cash dividends. Wu and Zhang (2017) believe that there is a negative correlation between corporate financing constraints and cash dividend policy, and the improvement of financial development level can significantly alleviate the negative correlation between corporate financing constraints and cash dividend policy.

For company performance, financing constraints have indirect effects on corporate performance. On the basis of empirical research, Cen and Tong (2015) find that financing constraints weaken the diversification of enterprises, and weakens the negative effect of diversification on enterprise performance. $\mathrm{Li}$ and $\mathrm{Xu}$ (2011) argue that when short-term securities become a potential financing tool for enterprises, enterprises that can use this financial tool have greatly improved their debt and investment capabilities, thus reducing the financing constraints and increasing their business performance.

This paper reviews the relevant research on financing constraints, focusing on the causes of financing constraints, the influence of financing constraints (section 1), and summarizes how to relieve financing constraints (section 2), and finally gives the conclusion (section 3).

\section{Relief of financing constraints}

Financing constraints restrict the investment of enterprises, which is one of the bottlenecks in the process of enterprise development. The relief of financing constraints is of great significance to the development of companies. In the existing literature research, this paper summarizes several main ways to relieve financing constraints as follows.

Improving information transparency is one way to relieve financing constraints since information asymmetry is the main cause of financing constraints. Dhaliwal et al. (2011) note that the social responsibility information disclosed by enterprises in the current period will reduce the capital cost of enterprises in the next period. Further research by Qian, Xu and Shen find that corporate social responsibility information disclosure can help relieve financing constraints. Li (2018) believes that improving the financial transparency of enterprises can effectively reduce the information asymmetry between enterprises and financing institutions, strengthen the ability of enterprises to obtain external financing, and relieve the financing constraints of enterprises.

Reasonable handling of agency problem would be another method to relieve financing constraints. Investors can supervise and restrain the financiers by acquiring corporate governance rights. On the one hand, this approach can effectively protect the rights and interests of clients, on the other hand, enterprises can also achieve the purpose of relieving financing constraints (Ai and Wei, 2004).

Reducing transaction costs is also a good way to relieve financing constraints. Li (2011) believes that enterprises can get more financing opportunities with smaller financing costs by establishing good cooperation and mutual assistance relationship with banks and becoming a member of "highquality customer group" of banks. Ge (2017) concludes that agency costs can be reduced by M\&A, thus reducing transaction costs and relieving financing constraints.

In addition, the government should perfect the financial systems since the financial enviorment can affect the financial constraints faced by the enterprises. Based on the perspective of financial development, Rajan and Zingales (1998) examine the impacts of regional financial development on 
corporate financing constraints. Their research shows that the improvement of regional financial development can help enterprises obtain more external capital. Claessens and Laeven (2003) point out that the level of financial development of a country affects the choice of external financing channels and determines the resources available for investment, thus affecting the growth of enterprises. Jin, Kong and Hou (2012) examine the impact of monetary policy on financing constraints and investment efficiency of private enterprises. They show that loosing monetary policy reduces the financing constraints of private enterprises. Xie and Huang (2014) conclude that loose monetary policy can relieve the financing constraints of enterprises and improve the financial ecological environment of enterprises by reducing the sensitivity of internal cash flow of enterprises' investment.

\section{Conclusion}

The purpose of this review is to propose feasible suggestions for enterprises to relieve financing constraints. Through reviewing the causes and effects of financing constraints, the review gives some ways to relieve financing constraints. Firstly, improving information transparency can relieve the financial constraints by reducing information asymmetry. Enterprises should provide more channels for outsiders to know the operating and financial conditions. Secondly, dealing with the agency problem properly can protect the clients' rights and interest, which can relieve the financial constraints by reduce the risk in the agency problems. Thirdly, enterprises should maintain good relationships with the fund providers, which can relieve financial constraints by reducing transactions costs. Besides, the function of the government is important since loose monetary policy is conducive to improving financial environment and relieving the financing constraints of enterprises.

\section{References}

[1] M. F. Mcnichols, S. R. Stubben, "Does Earnings Management Affect Firms' Investment Decisions?” The Accounting Review, Vol. 83, pp. 1571-1603, Nov 2008.

[2] G. Biddle, G. Hilary, “Accounting Quality and Firm-level Capital Investment," The Accounting Review, Vol. 81, pp. 963-982, Jan 2006.

[3] F. X. Jiang, B. B. Shi, and Y. B. Ma, "Information Releasers' Financial Experience and Corporate Financial Constraints,” Economic Research Journal, Vol. 51, pp. 83-97, 2016.

[4] H. J. Li, "Government Quality, Financial Transparence and Firm Financing Constraint: An Analysis based on Questionnaire Data of Chinese Manufacturing Enterprises," Commercial Research, Vol. 3, pp. 57-66, 2018.

[5] N. Foley-Fisher, R. Ramcharan, and E. Yu, "The Impact of Unconventional Monetary Policy on Firm Financing Constraints: Evidence from the Maturity Extension Program," Journal of Financial Economics, Vol. 122, pp. 409-429, Nov 2016.

[6] M. Campello, J. R. Graham, and C. R. Harvey, "The Real Effects of Financial Constraints: Evidence from a Financial Crisis," Journal of Financial Economics, Vol. 97, pp. 470-487, 2010.

[7] Y. M. Chen, W. Wen, Q. K. Sun, and Y. T. Huang, "Monetary Policy, Financing Constraints and Enterprise Foreign Direct Investment," Review of Investment Studies, Vol. 37, pp. 4-23, 2018.

[8] W. C. Ma, S. Y. Hu, "Monetary Policy, Credit Channel and Capital Structure," Accounting Research, Vol. 11, pp. 39-48, 2012.

[9] H. Almeida, M. Campello, and M. S. Weisbach, "The Cash Flow Sensitivity of Cash," Journal of Finance, Vol. 59, pp. 1777-1804, Aug 2004.

[10]A. A. Rampini, S. Viswanathan, "Collateral and Capital Structure," Journal of Financial Economics, Vol. 109, pp. 466-492, Aug 2013. 
[11]Y. Quan, S. K. Liang, and Y. X. Fu, "Monetary Policy, Financing Constraints and Cash Dividends," Journal of Financial Research, Vol. 11, pp. 63-79, 2016.

[12]C. X. Wu, J. Zhang, “An Analysis of Financial Development and Cash Dividend Policy: A Test based on Financing Constraints and Free Cash Flow," Commercial Research, Vol. 6, pp. 69-78, 2017.

[13]W. Cen, N. Q. Tong, "Financing Constraints, Corporate Diversification and Firm Performance," Commercial Research, Vol. 2, pp. 96-103, 2015.

[14]D. Dhaliwal, O. Li, A. Tsang, and Y. Yang, "Voluntary Nonfinancial Disclosure and the Cost of Equity Capital: The Initiation of Corporate Social Responsibility Reporting," The Accounting Review, Vol. 86, pp. 59-100, Jan 2011.

[15]M. Qian, G. X, Xu, and G. Shen, “Social Responsibility Information Disclosure, Accounting Conservatism and Financing Constraints: From the Perspective of Heterogeneity of Property Rights," Accounting Research, Vol. 5, pp. 9-17, 2016.

[16]H. D. Ai, W. Wei, "Corporate Governance and Solution of Information Asymmetry between Investors and Financers in Securities Market," Journal of Financial Research, Vol. 10, pp. 8493, 2004.

[17]F. Li, "Earnings Quality Based on Corporate Investment Decisions," Journal of Accounting Research, Vol. 49, pp. 721-752, June 2011.

[18]J. G. Ge, "Relieving Effect of M\&A on Financing Constraints of Target Listed Companies," Accounting Research, Vol. 8, pp. 68-73, 2017.

[19]S. Claessens, L. Laeven, "Financial Development, Property Rights, and Growth," Journal of Finance, Vol. 58, pp. 2401-2436, Dec 2003.

[20]Q. L. Jin, X. Kong, and Q. C. Hou, "Monetary Policy, Investment Efficiency of Private Enterprises and Company Option Value," Economic Research Journal, Vol. 47, pp. 96-106, 2012. 